\title{
TO WHAT EXTENT SHOULD CONGRESS APPROPRI- ATE TO DISTRIBUTE THE BURDEN OF WAR LOSS, GIVEN THE INSUFFICIENCY OF WAR REPARATION
}

\section{Joseph STETLER*}

This discussion is predicated upon the conclusion that Congress should take some affirmative action to satisfy war losses, given the insufficiency of reparation. The basis for that conclusion and the question of the extent of the satisfaction to be afforded involve a variety of considerations. The preponderance of these factors are matters of record; however, the recommendations and suggestions offered are based on my personal appraisal of the obligations of our Government in the matter and the most effective manner of providing relief.

It is true that there is no definite legal obligation, under recognized concepts of international law, which requires a government to secure indemnification for the war losses of its nationals. Further, it cannot be flatly asserted that the settlement of such losses is more compelling than the many social and economic considerations incident to the negotiation of peace treaties and other international agreements. Still, the claims to be considered are based on violations of well-established principles of international law, and as victims of such violations, claimants have the right to expect their government to press their claims for adequate compensation.

The complex character of war losses, the diversity of responsibilities, the variety of legal means available to achieve indemnification, and the legal obstacles to. surmount in the process, necessitate a complete governmental inquiry prior to any determination as to comparative equities. Unfortunately, the obligation to conduct a comprehensive study of this type has not been fulfilled.

The Eightieth Congress did authorize ${ }^{1}$ the preparation of a report concerning war claims by the War Claims Commission. In authorizing the preparation of the report, the importance of obtaining an overall picture of war claims before attempting to provide for their settlement was apparently recognized for the first time. This recognition is expressed in the language of the Interstate and Foreign Commerce Committee of the House of Representatives, in reporting the bill which became Public Law 896, 8oth Congress, wherein it was stated:

The question of war claims and debt claims is too complex to be approached by the Congress on a piecemeal basis .... the subject in its entirety must be studied thoroughly before any intelligent action can be taken by the Congress with respect to any particular aspect of war claims and debt claims. ${ }^{2}$

- LL.B. 1938, LL.M. r940, Columbus University, Washington, D. C. Member of the District of Columbia bar. Director, Legislation and Opinions Service, War Claims Commission. Editor of the REPORT of the War Claims Commisston Concerning Claims. Arising Out of World War II (H. R. Doc. No. 580, 81st Cong.).

${ }^{1}$ Sec. 8, Pub. L. No. 896, 8oth Cong., July 3, 1948 (62 Stat. I240).

2 Report of House Interstate and Foreign Commerce Committee on H. R. 4044 (Rep. No. 976, 8oth Cong.). 
However, the personnel and time necessary to achieve a truly complete survey were not provided. As the War Claims Commission pointed out in its report, if an exhaustive survey is desired, it will be necessary to provide adequate time and sufficient funds to accomplish the task.

Aside from the problem of what claims should be paid and the equitable treatment of various types of claimants with respect to priorities, there is also involved the fundamental problem of the ultimate source and amount of the funds to be used for satisfaction. This problem is intimately connected with the reparation to be paid by the German and Japanese governments, and the burdens in general which the economies of these two countries may be expected to bear.

.The reparation problem is and has been one of the most important and pressing questions with which representatives of this Government have had to deal. Despite the reparation policies adopted to date, it is felt that the obligation still exists for our Government to acquaint itself fully with the equitable and meritorious claims arising out of the war and to insure settlement whenever possible.

$\therefore$ If, after a thorough acquaintance with the number, types, and bases for such individual claims, it is determined that even partial satisfaction through reparation cannot be obtained, then another source of satisfaction must be sought. Regardless of the final reparation policy adopted the moral obligation of the government to secure indemnification for certain of these claimants remains.

\section{Definition of the Term "War Losses".}

.. In its broadest sense the term war losses may include all costs of war. However', for the purpose of this discussion no such meaning is intended. The extent of the Congressional responsibility for providing indemnification, referred to herein, is predicated upon a more selective interpretation. This interpretation is dependent upon the existence of a recognized legal or equitable basis for the claim, a close proximity of its cause to the war, existence of an obligation on the part of the government to furnish protection to the claimant, and the non-existence of a satisfactory measure or means of relief.

$\therefore$ The language expressing the distinction in international law between "war losses" and "war claims" varies from source to source, but the controlling idea is that actions, when performed in the ordinary conduct of hostilities, occasion no duty to pay damage for injuries resulting therefrom, whereas acts not normally incident to hostilities do give rise to such a duty. ${ }^{3}$

There is no intention to impute any obligation with respect to those war claims which have already been recognized and settled through the numerous domestic and international measures adopted during and after World War II.

. 5 G. H. Hackworth, Digest of International Law 633-634 (1940); 2 Marjorie M. Wiliteman, Damages in International. LaW $1384,1421,1434$ (1937). 
II

\section{Equitable and Legal Bases for War Claims Generally}

The principal bases for claims arising out of World War II are to be found (a) in international agreements, treaties, conventions, and exchanges of notes; (b) in existing domestic law of the United States; and (c) in implicit principles, sometimes called the international common law, which govern the behavior of civilized nations.

The existing body of international law is reasonably clear on such matters as the violence permissible to belligerents, the conduct of seizure, the limitation of devastation, retaliation, and russes, the treatment of enemy aliens and alien property, and the treatment, of. the wounded and prisoners of war. ${ }^{4}$ It is the behavior falling outside of these and similar well-defined limitations, however, which creates diffculties in the classification and evaluation of war claims. .. . .

\section{III}

\section{Types and Categories. of Enforçable, Wak Clatms}

"It is well. established that enemy governments. owed certain obligations.to the person and property of members of the United Statẹs Armed Fơrces, and the Unitẹd States civilians within their territories: .

.. Thus, the claims of the United States nationals againșt enemy governmențs are individual claims based on the specific nature and. degree of maltreatment receivẹd, and, therefore, are the property rights of such individuals. There can be little doubt, in the face of overwhelming evidence, of the wholesale violation of the written and implied rules of warfare. The brutality and malicious deprivation of human necessities, and life itself, practiced by enemy governments, have been estąblished beyond any doubt, not only by the testimony of the thousands who suffered at their hands, but also by the wealth of written evidence which has been uncovered since the termination of hostilities.

The results of these violations are likewise well established. The fact of malnutrition and undernourishment in virtually all of the camps where American military or civilian personnel were detained in World War II has been established. The degree of malnutrition varied, of course, with each camp and with the length of time each individual was detained. The wanton destruction, confiscation, and misappropriation of the property of the United States nationals has also given rise to innumerable property claims.

For present purposes the meaning of war losses is restricted to the following types of claims:

I. Claims based on death, personal injury, detention, etc.

(a) Claims by prisoners of war and civilian internees or their survivors. Loss of life, not the result of natural causes or combat activities.

- 6 Hsckwortz, op. cit. supra note 3, at 175-259. 
Improper treatment, including starvation; cruelty, such as physical violence and inhuman treatment; injuries; forced labor; inadequate housing, medical care, clothing, and sanitary facilities; and denial of proper pay and privileges.

After effects of imprisonment, including permanent disability or impairment of health, physical or mental, resulting from imprisonment.

(b) Claims by military personnel or civilians who went into hiding in order to avoid capture or internment.

2. Claims based on property loss, damage, etc.

(a) Loss or destruction of property, real or personal.

(b) Damage or injury to property, real or personal.

(c) Seizure, requisition, or removal of property, real or personal.

(d) Claims arising out of unusual expenditures occasioned by the war.

(e) Denial of use of property, real or personal.

\section{IV}

\section{Present Sources of Religf Availabì}

The extent to which claims arising out of World War II have been or may be satisfied is extremely difficult to determine with precision because of the scope of existing international agreements and foreign and domestic laws, the piecemeal manner of their negotiation or enactment, and the variety of definitions of the term "war claims" which have been adopted.

With respect to domestic legislation, the machinery which existed prior to the war for accepting and settling claims against the Government was utilized during the war and, in certain instances, is still functioning. In addition, numerous temporary and emergency measures were adopted during and after the war which also deal in part with the recognition, receipt, and adjudication of war claims. To this extent Congress has already distributed the burden of war losses by direct appropriation.

- A search of the Statutes at Large since the Seventy-Fifth Congress indicates that äpproximately fifty Public Laws have been enacted which in some manner recognize and provide for the satisfaction of war losses. This legislation can be categorized generally as War Insurance Legislation, Military and Naval Claims Legislation, Re; habilitation, Indemnification, and Relief Legislation, and War Contracts Legislation: These categories do not include, of course, the various acts passed in the last ten years for the benefit of veterans. It is questionable, however, whether the majority of such enactments can be considered as claims legislation in as much as they are, in a large measure, designed to grant gratuitous benefits rather than to comperisate legally enforceable claims.

In considering the role of the courts in this matter, it is apparent that a volume of war claims of one type or another has been and will be the subject of private and governmental litigation. In addition to the functions of the numerous state and 
federal courts, and of the Tax Court with respect to contract cases, the Court of Claims would appear to play a prominent part.

In determining the measure of satisfaction of war losses provided by international agreements and foreign legislation, one of the basic matters for consideration is a discussion of the pertinent provisions of the treaties of peace already in force. This consideration will be reserved, however, until the subject of reparation is discussed. It should be borne in mind, however, with reference to the Treaties of Peace with Bulgaria, Hungary, and Rumania, that the practice of those governments in settling war claims is not in conformity with the obligations created by the treaties.

In addition, numerous other avenues of relief, through lend-lease and war account settlement agreements and agreements on a military level, are available for intergovernmental claims, and to some extent for claims resulting from torts committed by the forces of the parties to the agreements.

Basic to any consideration of the status of war claims is the principle, well established in international law, that a claimant before seeking the interposition of his own government in his efforts to obtain satisfaction for his claim must first exhaust whatever local remedies are available in the country against whose government his claim lies. ${ }^{5}$

Exceptions to this principle have been recognized, where justice is wanting; where local remedies have been superseded; where the remedy is insufficient; where unjust judgments have been rendered; or where unjust discrimination is practiced against such nationals. ${ }^{8}$

In the majority of instances the availability of satisfactory settlement through foreign legislation or local remedies is definitely limited. There are governments, however-for example, The Netherlands-which have developed a fairly comprehensive system for satisfying war claims relating to property loss or damage. In these instances an avenue of relief is available and must be pursued before relief can be sought through our government's intervention.

\section{$\mathrm{V}$ \\ Precedents for Únited States War Clatms Policy}

The development of American principles of protection applied to national and foreign claimants has been reflected in our past international arbitrations. This development has been of wide influence and consonant with the legal philosophy of this nation to do what is right and just. Reference to the authorities ${ }^{7}$ will reveal in detail the history, jurisdiction, and decisions of such tribunals to which the United States was a party.

Settlement of war claims and the affording of relief to nationals of the United

' 6 John B. Moore, A Digest of International Law $\$ 987$ (Igo6).

- MOORE, Op. cit. supra note 5, \$\$988 through 992.

' I John B. Moore, History and Digest of the INTERnational Arbitrations To Which the Unith' States Has Been a Party (1898). 
States suffering as a result of war have generally been effected by the creation of international tribunals. Despite the fact that the handling of claims arising out of earlier wars, in terms of number and value, was relatively simple, their settlement has nevertheless usually been accompanied by prolonged and discouraging delays.

In the interest of sound international relations and for the immediate equitable compensation of the claims of our nationals, it seems that the method of settlement is secondary in importance to the need for some settlement, whatever it may be.

\section{VI}

\section{United States Policy Following Wordd War I}

- Under date of July 2, I92I, the Congress declared the first World War between the United States and Germany ended. By the same action, all of the rights of the United States and its nationals under the armistice were reserved, and the United States was permitted to retain certain eremy property held by it.

A month later, by the Treaty of Peace with Germany, ${ }^{8}$ signed at Berlin, August 25, I921, and proclaimed by the President, November I4, 1921, the United States was granted all of the rights and privileges specified in the Act of July 22, I92ir, as well as all of the rights and advantages stipulated in the Treaty of Versailles which were to be accorded by Germany.

Annex I of the Treaty of Versailles of June 28, 1919, set forth a detailed list of the types of recognizable claims of the Allied or Associated Powers for which Germany would be responsible.

As an outgrowth of the above-referred-to treaties, the United States and Germany signed the Executive Agreement of August ro, 'ig22, ${ }^{2}$ agreeing to the establishment of a Mixed Claims Commission to determine the amount to be paid by Germanthy in satisfaction of Germany's financial obligations under the Treaty of Berlin.

The first article of that Treaty. set forth the categories of claims which were to be handled by the Mixéd Claims Commission in much more general form thàn did the Treaty of Versailles. These categorities were as followis:

(I) Claims of American citizens ąrising after July 3r, r914, in respect to damage to, or seizure of, their property, rights, and interests, including any company or association in which they were interested, within German territory às it existed on August $\mathrm{r}, \mathrm{rg1} 4$;

(2) Other claims for loss or damage to which the United States or its! nationals had been 'subjected with respect to' injuries to persons, or to property rights and interests, including any company or association in which American nationals were interested, after July $3 \mathrm{x}$, $19 \mathrm{r}_{4}$, as a consequence of the war;

(3) Debts owing to American citizens by the German Government or by German nationals. 
It was not, however, until the passage of the Settlement of War Claims Act of I928, ${ }^{10}$ that provision was made for the payment of the awards of the Mixed Claims Commission. Under section 4 of that Act, the awards entered by the Commission were divided, for the purpose of establishing a priority of payment, into ithree classes: Class I, awards on account of death and personal injuries; Class II, awards, other than for death and personal injuries, of $\$ 100,000$ or less stated as of January $\mathrm{I}$, I928; and Class III, all awards, other than for death and personal injuries, in excess of $\$ 100,000$ stated as of January $\mathrm{T}$, I928.

During the life of the Mixed Claims Commission a total of 20,433 claims were filed. Awards were allowed in about one-third or 7,20r cases, involving one of the 'three classes of claims indicated above. The breakdown as to the number and value of such awards plus interest is as follows: $:^{11}$

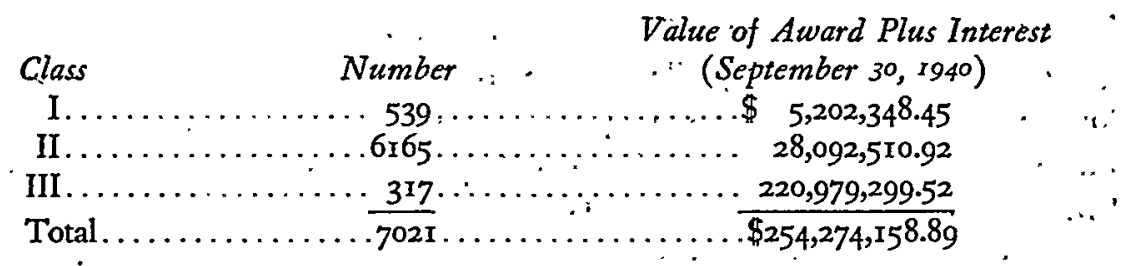

It is interesting to note that as recently as the last session of Congress a bill ${ }^{12}$. was introduced to authorize the appropriation of the sums necessary to pay the balance of certain adjudicated but unpaid awards of the Mixed Claims Commission.

The best available information indicates that the principal and interest due in such cases amounts to approximately $\$ 98,0,00,000$. .

Hearings were held on the bill, but it was not enacted into law.

\section{VII}

\section{Sources of Funds for Providing Indemnification}

It is possible that there are other sources of funds available for indemnification; however, consideration here has been reserved to four: Reparation; Proceeds from Liquidated Vested Enemy Asssets; Transfer of Miscellaneous Funds; and General Legislative Appropriations. The distinctive rationale incident to the use each of these sources indicates an individual treatment.

\section{A. Reparation}

The ramifications of the problem incident to the exaction of reparation from a defeated nation are many. Although our position has been made rather clear by a succession of events, meetings, pronouncements of policy, and agreements, it will not become a completely closed issue as long as the Treaties of Peace with Germany and Japan remain to be negotiated.

\footnotetext{
${ }^{10}$ Pub. L. No. 122, 7oth Cong., March ro, rg28 (45 Stit. 254).

11 Final Report of H. H. Martin, Acting Agent of the United States Before the Mixed Clians Commission, United States and Germany 93 (I94I).

${ }^{32}$ H. R. 6074, 8Ist Congress.
} 
Although there is a strong moral objection to the idea of a defeated enemy escaping obligation for the property damage, destruction, and the human suffering which it caused during a war, no one seriously suggests that we adopt a policy which is going to deprive the nationals of Germany and Japan of the means of providing for themselves. First, it is not our nature; and secondly, history has demonstrated that the exaction of heavy reparation is accompanied with adverse after effects.

The indemnity exacted by Germany from France under the Treaty of Frankfurt in $187 \mathrm{I}$ was roughly one billion dollars. The year following this settlement was marked by a period of prosperity in France and depression in Germany. These facts give color to the story that Bismarck, in commenting upon the economic status of the two countries, disclosepd that the next time he defeated France he would demand that Germany be permitted to pay the indemnity.

No attempt will be made here to discuss the present or future economic ability of the German or Japanese Governments to pay reparation. However, it is felt, as previously stated, that regardless of the considerations which dictate the final terms of the peace settlements, the obligation still exists for our Government to determine the equitable and meritorious claims arising out of the war and to insure settlements from this source in so far as possible.

The attempts to exact reparation from Germany after World War I are largely responsible for the unpleasant connotations attached to that word. Initially the United States vacillated between a policy favoring the disclaimer of reparation due under the Treaty of Versailles and its ancillary treaties, and an occasional switch to the policy preferred by the participating Allied Powers. Ultimately a reparation debt was created, but despite German overtures it remained always just a debt.

The sums eventually paid in reparation were much more than balanced by German net borrowing of capital and credit from the rest of the world. This condition continued until, in the midst of a world depression, it.became apparent that the only logical course was the complete abandonment of reparation.

In their report on the Crimean Conference, dated February Ir, 1945, the Big Three for the first time issued a statement on reparation. A special section of the Crimea Declaration devoted to the problem provided, with respect to reparation from Germany:

We have considered the question of the damage caused by Germany to the Allied Nations in the war and recognized it as just that Germany be obliged to make compensation for this damage in kind to the greatest extent possible. A commission for the compensation of damage will be established. The Commission will be instructed to consider the question of the extent and methods for compensating damage caused by Germany to the allied countries. The Commission will work in Moscow.

Although the Reparation Commission was activated and accomplished its pre: liminary work, appreciable progress was not made until the Potsdam Conference. The agreement arising out of that Conference contained an interim program of reparation from Germany. 
Subsequently, the United States, the United Kingdom, and France divided their reparation shares, derived from the Potsdam agreement, with fifteen other nations by the Paris Agreement on Reparation from Germany, January 14, 1946. The term "reparation" within the context of such report and agreements has the meaning of compensation for damages. Further, it appears clear that whatever reparation is to be made will be made primarily in kind and not in money.

The Crimea Declaration and the Potsdam Agreement also postulated, as a basic principle of reparation policy, that distribution of German reparation assets was to be based on the extent to which an Allied Power suffered from war damage and the extent of its participation in actions leading to victory. As a result of this principle, a special share of German reparation payments was provided for the Union of Soviet Socialist Republics and Poland on the one hand and the other Allied Powers on the other. Within the latter group is included the United States.

As a result of a report made by the Economic Cooperation Administration our Government and the Governments of France and the United Kingdom entered into an agreement on March 3I, I949, which provided for the removal of a limited and specified number of plants. A further agreement, known as the Petersburg Protocol, was entered into on November 22, I949, between the High Commissioners of the three powers occupying the western zones of Germany and the Chancellor of the German Federal Republic. By this Agreement, certain specified industrial plants were marked for removal. Agreement was also reached precluding further removals for reparation.

The fact that our present stated policy, as disclosed by the report of January I4, I949, and the aforementioned agreements, precludes further reparation removals from Germany in all probability means that reparation from Germany will be insufficient to meet war claims of United States nationals against Germany.

The Allied Powers by the Potsdam agreement further stated that the basic policy of reparation from Japan would be reparation in kind sufficient to end the Japanese war potential but not so oppressive as to disrupt the basic economy of the country. This concept of reparation was accepted by the Japanese Government under the terms of the surrender of September 2, r945.

Initially, the Far Eastern Commission, which came into being as a result of decisions reached at the Moscow meeting of the Foreign Secretaries on December 27, 1945, promulgated a series, of policy decisions concerning reparation removals of industrial property from Japan. This program failed to make progress because of the absence of an agreement among the governments potentially entitled to a reparation share as to the percentage of reparation to be allocated. Efforts of the United States to end the impasse were unsuccessful.

In a statement ${ }^{13}$ outlining the position of the United States concerning the future exaction of reparation. from Japan, General Frank R. McCoy stated, in part: . . .

${ }^{13}$ Statement, dated May I2, r949, by General Frank R. McCoy, United States representative. on the Far Eastern Commission, concerning Japanese reparation and level of industry. (Italics supplied.) 
It is the considered view of the United States Government that this objective does not require that Japan's production for peaceful purposes be limited or that limitations be imposed on levels of Japanese productive capacity in industries devoted to peaceful purposes. This belief, coupled with the evidence of Japan's present economic plight and the difficult problems Japan will face in the future in attaining levels of industrial production and foreign trade sufficient to support its people even at minimum levels, render it clearly advisable in my Government's vieu that Japan be permitted to develop its peaceful industries without limitation. The problem facing us is not one of limitation of Japan's peaceful industries but of reviving these industries to provide the people's barest wants.

The effect of this pronouncement was the rescission by the United States of an earlier interim directive on reparation removal and, in effect, the termination of the entire program for the removal of reparation from Japan.

The. Paris Agreement on Reparation from Germany, which became effective January 14, 1946, was participated in by the United States and 17 other nations. It provided for the percentage participation of the Allied Powers in German assets subject to reparation. :

$\therefore$ The United States, under the terms of the Paris Agreement, is to receive stated percentages of. all German assets subject. to reparation payments. In addition, the United States of America is to retain control over German assets within its jurisdiction which are now subject to the control of the Öffice of Alien Property, Department of Justice.

The Paris Agreement further stipulated that the signatory governments agree among themselves that their respective reparation shares are regarded by them as covering all of their claims and the claims of their nationals against the former German Government and its agencies, which claims arose out of the war and are not otherwise provided for.

It is worth noting that although the reparation shares assigned by the Paris Agreement are based, in part, on a consideration of private losses resulting from war damage to property, the allocation of reparation is made, not to the individuals, but to the several governments involyed. The compensation of private persons who hold claims against Germany arising out of the war is a matter for the Allied Governments to handle in accordance with their respective governmental procedures.

\section{I: Peace Treaties Negotiated to Date}

A general peace conference of the twenty-one nations which participated in the war against Germany, met in Paris on July' 29, I946, to consider the terms of Péalce Treaties with Italy, Hungary, Rumania; and Bulgaria. This conference had its origin in the Potsdam Conference.

In discussing the stipulations concerning the recognition and settlement of war 'claims' contained in the péace tréatiès negotiated to date my comments will be extremely general in nature. No attempt is máde herein to outline all of the pertinent clauses of each of the treaties. 
a. Italy. The Treaty of Peace with Italy ${ }^{14}$ provides for the restitution of property to the United States ${ }^{15}$ and for the indemnification of the United States or its nationals for loss or damage to property in Italy, territories ceded by Italy, and the Free Territory of Trieste. ${ }^{16}$

Those eligible for restoration of property and for indemnification for damage to, or loss of, property include individuals who were American nationals, corporations, or associations organized under the laws of the United States at the time the Treaty came into force, provided that such individuals, corporations, or associations were also American nationals on September 3, r943, the date of the armistice with Italy. Individuals, corporations, or associations which were treated as enemy under the laws in force in Italy during the war are also eligible claimants. ${ }^{17}$

The general policy of the indemnification and restoration provisions of the Treaty of Peace with Italy is to provide for the restoration or return of the property, legal rights, and interests of the United States of America and its nationals as such existed on June Io, r 940 .

In the event that disputes arise under the clause's relating to indeminification and restitution, the final decision is to be made by a conciliation commission. : : : '

On August 14, 1947, a "Memorandum of understanding regarding settlement of certain wartime claims and related matters" and a "Memorandum of understanding regarding Italian assets in the United States of America and certain claims of United States nationals" were signed in Washington by-Robert A. Lovett, Acting Secretary of State, on behalf of the United States, and Ivan Matteo Lombardo, Chief of the Italian Economic and Financial Delegation, on behalf of Italy:

- These memoranda and certain supplementary notes, ordinarily referred to as the "Lombardo Agreement," generally reaffirmed provisions of the Peace Treaty, and provided specific detail as to the interpretation of some of the broad terms contained therein. Both nations agreed to waive certain enumerated claims which might arise under the $\cdot$ Treaty.

Provision was also made, under certain conditions, for the return of vested propêrty and the unblocking of frozen Italian assets. In return, the Italian Government agreed to place at the disposal of our. Government the sum of $\$ 5,000,000$ to be used in meeting war claims of United States nationals for which there was no other provision in the Treaty of Peace or in the agreement:

The Italian-American Conciliation Commission: was created according to Article 83 of the Treaty of Peace.with. Italy:i Any disputes involving the United States or its nationals which may arise under Articles 75 or 78 of the Treaty, or ûंnder certaiti specified annexes, will be referred to this Commission which consists: of one representative from each of the two Governments. If 'within three 'months after the .1. ${ }^{14}$ This Treaty: was signed at Paris; on February 10,1947 , and came into force on Septembèr 15 , 1947, 6r Stat. 1245, 8oth Cong., Ist Sess. (r947).

${ }_{15}$ Art. 75, Treaty of: Peace with Italy:

${ }^{27}$ Art. 78, Treaty of..Peace: with Italy.:

${ }^{16}$ Art. 78 , Treaty of:Peace: with Italy." $\therefore$ 
dispute has been referred to the Conciliation Commission, no agreement has been reached, either Government may ask for the addition of a third member to the Commission, selected by mutual agreement from nationals of a third country.

b. Bulgaria, Hungary, and Rumania. ${ }^{18}$ The Treaties of Peace with the former enemy governments of Bulgaria, Hungary, and Rumania provide for the restitution of property to the United States, ${ }^{19}$ and for the indemnification of American nationals who suffered loss or damage to their property in territories of such former enemy governments. ${ }^{20}$

Individuals who are American nationals, or corporations or associations organized under the laws of the United States, and who were nationals at the time the Treaties of Peace came into force are eligible for indemnification, provided that such individuals, corporations, or associations were also American nationals on the respective dates of the armistices with the former enemy governments. ${ }^{21}$ Individuals, corporations, or associations which were treated as enemy under the laws in force in the territories of the former enemy governments during the war are also eligible claimants. $^{22}$

In the Treaties with the Governments of Bulgaria and Hungary, the property subject to indemnification is defined as all movable or immovable property, whether tangible or intangible, including industrial, literary, and artistic property. Also included are rights or interests of any kind in property. ${ }^{23}$ In the Treaty with the Government of Rumania, in addition to the above property, there are also included certain seagoing and river vessels and the equipment thereon.

The general policy of the indemnification and restoration provisions of the Treaties of Peace with these former enemy governments is to provide for the restoration or return of the property, legal rights, and interests of the United States of America and its nationals. In the Treaty of Peace with Bulgaria the date for determining the nature, extent, and status of the rights of the Government of the United States of America and its nationals is April 24, 1941. ${ }^{24}$ In the Treaties of Peace with Hungary and Rumania, the controlling date is September I, $19390^{25}$ . In the event that disputes arise under the clauses relating to indemnification and restitution, the decision is to be made by a conciliation commission consisting of an equal number of representatives of the Government of the United States of America and of the former enemy government. Procedures are also established for the selection of a third member of the Conciliation Commission if agreement cannot be reached.26

${ }^{18}$ Bulgaria (6r Star. 1915); Hungary (6I STAT. 2065); and Rumania (61 STAт. 1757). All three Treaties were signed at Paris on February 10, 1947, and came into force September 15, 1947.

${ }^{10} \mathrm{~B}$ Art. 22; H. Art. 24; R Art. 23. ${ }^{20} \mathrm{~B}$ Art. 23; H. Art. 26; R Art. 24.

${ }^{21}$ Armistice with Bulgaria, October 28, I944; with Hungary, January 20, 1945; with Rumania, September 12, 1944.

${ }_{22}$ B Art. 23; H Art. 26; R Art. 24. $\quad{ }^{23}$ B Art. 23; H Art. 26.

$24 \mathrm{~B}$ Art. 23.

${ }^{25}$ H Art. 26; R Art. 24.

${ }^{20}$ B Art. 3I; H Art. 35; R Art. 32. 


\section{Prospective Treaties with Germany, Japan, and Austria}

a. Germany. Although the Treaties of Peace already negotiated may be looked to for guidance in any estimate of the probable nature of the Treaty of Peace with Germany, further special factors inherent in Germany's wartime and post-war position necessitate certain differences. Germany was the principal European aggressor, and, consequently, she is responsible for the greater portion of the claims which have arisen as a result of World War II.

The preceding discussion of the general policy of the United States regarding reparation and the specific provisions of the Paris Agreement indicate rather clearly what to expect in the way of claims settlements out of reparation derived from a Treaty of Peace with Germany. However, one of the major obstacles to any evaluation of the probable terms of a Treaty of Peace with Germany lies in the interpretation of the waiver stipulated by the Paris Agreement. If the waiver is deemed to be restrictive, our present policy on reparation in essence forecloses any possibility that the Treaty of Peace with Germany will provide effective compensation for war claims.

The extent to which this waiver is operative is in doubt in view of the fact that it is qualified so as to be without prejudice to a later determination of the forms, duration, and total amount of reparation to be made by Germany and the rights which a signatory government may have to the final settlement of German reparation.

b. Japan. If any substantial satisfaction of war claims against Japan is to be effected, it would appear that an essential element of any peace settlement with Japan, in so far as it relates to war claims, would be a provision setting forth the procedures necessary for the creation of a fund from which such war claims can be satisfied. This is especially important in view of the extent and nature of the personal injury claims for which Japan is liable. In addition, indemnification and restoration provisions similar to those obtaining in the existing peace treaties will also be necessary.

c. Austria. In as much as Austria was not an independent nation during World War II and was not at war with the United States, war claims arising in Austria are attributable to the activities of the former German Government. In the Foreign Ministers' declaration on Austria made at Moscow on November I, 1943, it was stated that the annexation by Germany of Austria on March 15, x938, was null and void, and that the intention of the Allied Powers was the reestablishment of Austria as a free and independent nation.

The then Secretary of State, James F. Byrnes, at the Council of Foreign Ministers in Paris, on May 20, 1946, announced that in accordance with the Agreement made at Potsdam in August of 1945, no reparation would be exacted from Austria.

B. Proceeds from Liquidated Vested Enemy Assets

By the passage of the Trading With the Enemy Act of ${ }^{1} 9 \mathrm{I} 7,{ }^{27}$ power was dele"Pub. L. No. 9r, $4^{\circ}$ Srat. 4 Ir, 65th Cong., Ist Sess. (19I7). 
gated to the President and the Alien Property Custodian to seize and control all property located in the United States owing or belonging to an enemy government or enemy national. These powers were exercised by our government during World War I and a large amount of enemy property was seized and converted to the use and benefit of the United States. However, in the post-war period the policy was softened and almost 80 per cent of the property seized was returned to its former owners.

During World War II the United States again exercised its power under the Trading With the Enemy Act: Pursuant to the provisions of sections 12 and 13 of the War Claims Act of $1948,{ }^{28}$ the War Claims Fund was established, consisting of certain proceeds of liquidated vested enemy property.

In a statement by Mr. Harold I. Baynton, then Acting Director, Office of Alien Property, Department of Justice, dated March $24,1950,{ }^{20}$ it was disclosed that the present net equity of the Office of Alien Property in vested property is $\$ 344,900,000$. This net equity is deemed to be subject to a probable payment of debt and title claims of between $\$ 35,000,000$ and $\$ 50,000,000$. Pending cases in the process of litigation, under section 9(a) of the Trading With the Enemy Act of r9r7, as amended, amount to $\$ 125,000,000$. On the basis of the figures, it appears that between $\$ 169,900,000$ and $\$ 184,900,000$ will eventually be available for transfer to the War Claims Fund.

However, it is believed that these estimates are' low in the light of two factors. First, it is extremely doubtful that all of the pending litigation under section 9(a) will result in the return of vested property. Therefore, in all probability, at least a portion of the aforementioned $\$ 125,000,000$ will eventually be available for transfer to the War Claims Fund. In addition, the Office of Alien Property is presently vesting additional assets at the rate of approximately $\$ 25,000,000$ per year. Undoubtedly, a portion of the newly vested assets will also eventually be available for transfer to the War Claims Fund.

By the passage of the War Claims Act of r948, Congress, in addition to authorizing a study of war claims, provided for the payment of claims (a) for detention; disability, and death by certain civilian internees who were interned or in hiding in specified Pacific areas; (b) for compensation by prisoners of war who did not receive adequate rations in accordance with the terms of the Geneva Convention of July 27, I929; (c) for reimbursement by certain religious organizations functioning in the Philippines, for services and supplies furnished to United States forces or United States citizens; and (d) for reimbursement or cancellation of repatriation expenses paid or owing by certain persons to the Department of State.

It is estimated that the cost of settling these claims will approximate $\$ 150,000,000$. Therefore, on the basis" of current figures, it appears that from $\$ 20,000,000$ to

- ${ }^{28} 62$ STAT. 1246, 2247 (1948), 50"U. S. C. App. \$́\$2011, 2012 (Supp. 1950).

${ }^{20}$ Hearings before Subeommittee of the House Committee on Interstate and Foreign Commerce on H. R. 6808, 700r, and other bills, 81st Cong., 2d Sess. 60, 6r, 62 (x950). 
$\$ 25,000,000$ will eventually be available for the sạtisfaction of additional war claims. It is possible that, by further vesting and by successful defense of section 9 (a) litigation cases, there may be available a sum in excess of $\$ 50,000,000$ for this purpose.

\section{Transfer of Miscellaneous Funds}

During the war and since the termination of hostilities, numerous miscellaneous accounts have been set up in the Department of the Treasury. Although in many instances these accounts have been merged with the general funds of the Treasury, they are of interest in exploring the possibilities for the settlement of war claims.

The accounts indicated do not reflect the previously referred to proceeds of the Office of Alien Property, nor is this list intended to include all of the accounts of this type. They are merely examples of the miscellaneous funds in question.

. In view of the fact that all of the amounts listed. represent income from either wartime governmental activities or proceeds from reparation from enemy countries, it would seem that consideration might justifiably be given to their use for the satisfaction of war claims. $U_{p}$ to date information concerning the status and amount of these funds is difficult to obtain. For that reason approximations or the latest available figures have been used:

Surplus of War Damage Corporation...... . . . . . . \$210,508,722.38

Proceeds of German property seized in Japan.......... 275,000.00

Proceeds from sale of German ships................ 2,334,233.00

Proceeds of German property seized in Spain......... $\quad$ 1,597,512.82

Surplus of funds to cover civilian war hazards............ $\quad 3,900,436.35$

Amount deposited by Italy pursuant to the

Lombardo Agreement................. . . . . . . 5,000,000.00

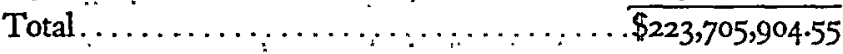

D. General Legislative Appropriations

A's indicated earlier Congress has already by some fifty Congressional enactments appropriated, in some measure, to distribute the burden of war losses. In breaking down this legislation into categories, reference is made to War Insurance Legislation; Military and Naval Claims Legislation; Rehabilitation, Indemification and Relief Legislation; and War Contracts Legislation. Although all of these types represent Congressional distribution of war loss, it is believed that specific enactments falling under the headings Military and Naval Cläims Legislation and Rehabilitation, Indemnification and Relief Legislation are most representative.

\section{Military and Naval Claims Legislation}

The Military Personnel Claims Act of $1945^{30}$ as amended, authorized the Department of the Army to compensate its civilian employees and military personnel for certain damage to or loss, destruction, capture, or abandonment of personal property incident to their service.

so 59 Star. 225. 
Under a later Act, December $28,1945{ }^{31}$ the power of the Department of the Navy to settle claims was made analogous to that of the Department of the Army under the Act, as amended.

Under the Foreign Claims Act, ${ }^{32}$ provision is made for settlement of claims for damages, personal injury, or death caused by members of the armed forces in foreign countries. Claims resulting from action by the enemy or resulting directly or indirectly from any act of our armed forces engaged in combat are excluded.

An Act of July 3, $19433^{33}$ as amended, authorized the Secretary of the Army or his designees to settle certain property and personal injury claims not cognizable under the Foreign Claims Act or the Military Personnel Claims Act. Under this Act, as amended, certain claims may be settled for damage to, or loss or destruction of property or personal injury or death, settlement of which is not precluded by the Federal Tort Claims Act, the Military Personnel Claims Act, or the Foreign Claims Act. Claims for personal injury or death are allowable only to the extent of medical, hospital, and burial expenses.

\section{Rehabilitation, Indemnification, and Relief Legislation}

Numerous legislative enactments could properly be discussed under this heading; however, for purposes of brevity only three will be considered.

a. Japanese Evacuees. It will be remembered that during the early stages of World War II, it was considered necessary for security purposes to put into effect a mass evacuation program of all persons of Japanese ancestry from the west coast of the United States to certain camps in the interior.

The American-Japanese Evacuation Claims Act was enacted on July 2, 1948. ${ }^{34}$ This Act authorized the settlement of claims of persons of Japanese ancestry for damage to, or loss of, certain real or personal property, which damage or loss was a reasonable and natural consequence of the evacuation program.

b. Guam. Legislation providing relief for the residents of Guam was enacted on November $15,1945^{35}$ Provision was made for settlement of certain property claims and meritorious death claims arising from hostilities or capture by the enemy or from non-combat activities of the United States Naval Forces.

Since the war, the Department of the Navy has provided an additional measure of relief for the inhabitants of Guam through the construction of Navy projects. However, no organized program for reconstruction of damaged or destroyed civilian facilities has been undertaken.

c. Philippines. The first important step taken by the Congress to repair damage caused by the war in the Philippines was the passage of the Philippine Rehabilitation A ct of $1946{ }^{36}$ which established the Philippine War Damage Commission.

3159 StAT. 662.

32 Act of January 2, 1942, Pub. L. No. 393, 77th Cong. (55 STAT. 880).

${ }^{33} 57$ STAT. 372.

${ }^{36}$ Pub. L. No. 886 , 8oth Cong. (62 STAT. 1231).

${ }^{35}$ Pub. L. No. 224, 79th Cong. (59 STAT. 582).

${ }^{30} 60$ STAT. 128, 50 U. S. C. App. 5 I751-1806 (1946). 
The Philippine War Damage Commission was authorized to adjudicate and pay up to a maximum of 75 per cent of the determined allowable amount for damage to certain types of tangible property. The remaining 25 per cent was to be paid by means of reparation or indemnity received by the United States from Japan on account of war losses in the Philippines, after the United States had reimbursed itself for funds appropriated under the Act.

Provision was also made for the construction and repair of certain public works such as highways and port facilities and the establishment of survey and training projects in the fields of public health, sea and air navigation, weather facilities, and coast and geodetic surveys.

\section{VIII}

\section{Conclusions}

It has often been suggested that provision for the payment of war claims, at least those in the high-priority groups, be made by direct appropriation from the general funds of the Treasury, without regard to possible reparation payments or the proceeds of liquidated enemy assets. It has been urged that such an approach would assure that any moral obligation of the Government to insure compensation of its nationals for war damage would not be dependent upon the uncertainties of future financial settlements with enemy countries or ultimate realization on vested enemy property.

Certainly it is idle to contemplate that more than a fraction of the costs of World War II and the claims arising out of it can be settled from enemy property now held or from indemnities later recovered. However, it is believed that before complete reliance for the settlement of war claims is placed upon direct Congressional appropriation, a vigorous attempt must be made to settle the maximum number of claims from the two sources indicated.

In considering the question of national policy as to enemy assets which have been blocked or vested, cognizance must be taken of the many bills which are pending in Congress which, if enacted, would dissipate the amount potentially available from this source for the settlement of war claims.

With the passage of time there is a growing pressure to again adopt the "soft" attitude which we fostered toward Germany shortly after World War I and to ignore and write off the war claims of American nationals. It is hoped that Congress will adopt a cautious attitude in this regard and that, before acting on the many pending bills which would amend the Trading With the Enemy Act, it will reacquaint itself with the uncompensated personal suffering and economic injury which resulted from the war.

Reparation as a source of settlement, as already indicated, is certainly not a closed issue. Before it becomes a closed issue, however, we should learn the complete story regarding the types, volume, and value of war claims. It is doubtful that in 
the settlements negotiated to date adequate consideration has been given to the personal injury, death, and property claims of American nationals.

It should be noted in this regard that under the Paris Agreement many claims of American nationals were waived. The Paris Conference which led to this Agreement was in session for little over a month. Certainly this was a short period for sufficient thought to be given to the extent of personal injury and property claims and for the reaching of an agreement concerning their disposition.

This view seems to be buttressed by the conditions prevailing with reference to the aforementioned Lombardo Agreement. From all information available the amount of $\$ 5,000,000$ which Italy gave for the settlement of war claims outside of the Treaty of Peace and the Agreement was: arbitrary.

In as much as the decisions have been made to discontinue both the German and Japanese reparation programs, the rights of American nationals with reference to the obtaining of satisfaction for war losses from reparation have at least temporarily been placed in abeyance.

What then regarding the reparation payments which have already been received? What legislative proposals have been put forward since January, I946, to implement the settlement of war claims out of the funds realized from reparation shares? What action has been taken to make available for the payment of war claims the $\$ 5,000,000$ obtained pursuant to the Lombardo Agreement? Unfortunately, the answer to each of thèse questions is in the negative.

Although a long delay will probably elapse before the status of sovereignty will be restored to Germany, a study group has been formed for the consideration of a pre-treaty settlement of war claims. With respect to Japan, preliminary peace treaty negotiations are under way. It appears, therefore, that the question of satisfaction of war claims by reparation will soon be settled.

For these reasons it behooves us to learn the full story on war claims before reparation is foreclosed as a source of war claims settlement.

An intelligent decision on this issue, combined with a vigilant policy with respect to blocked and vested enemy property, should provide for the settlement of a number of war claims. However, any insufficiency of assets from enemy governments or from the proceeds of vested enemy property will creaty an urgent need for the formülation of a legislative program' for resolving war damages. If we are diligent in our efforts to settle war losses from the sources now available, we can lessen the burden remaining for distribution by Congressional appropriations. The obligation to obtain indemnification is certain; the decision as to the amount to be settled by direct Congressional appropriation remains. 